Ray McKenzie MD FFarcs, Preyaratt Phitayakorn MD, Nonita T. Lim Uy MD, Jagadamba Chalasani MD, Brian' M. Melnick MD, Roland L. Kennedy MD, Albert F. Vicinie III BS

\title{
Topical bupivacaine and etidocaine analge- sia following fallopian tube banding
}

The purpose of this study was to compare the effectiveness and safety of etidocaine and bupivacaine for postoperative analgesia after laparoscope sterilization. The study was performed in 22 healthy patients who received either one per cent etidocaine, 2 $\mathrm{mg} \cdot \mathrm{kg}^{-1}$, or bupivacaine $1.5 \mathrm{mg} \cdot \mathrm{kg}^{-1}$ in a double-blind, randomized fashion. The local anaesthetic was dropped onto the fallopian tubes from uterus to fimbriae before tubal occlusion. To establish safety, blood concentrations of the parent drug and its metabolites were measured before application and at $1,3,6$, $10,15,30,60$ and $120 \mathrm{~min}$. The mean peak concentrations were $501.8 \pm 71.3$ (SEM) for etidocaine with a range of 225 to 905 $\mathrm{ng} \cdot \mathrm{ml}^{-1}$. For bupivacaine, the mean peak concentration was $468 \pm 73.8 \mathrm{SEM}$ with a range from $191101005 \mathrm{ng} \cdot \mathrm{ml}^{-1}$. The mean values are one eighth of the toxic convulsive dose for humans. Etidocaine was metabolized at a faster rate than bupivacaine with a rapid appearance of 2-amino-2'-butyroxylidide $(A B X)$. The bupivacaine metabolite 2,6-pipecoloxylidide $(P P X)$ was detected in low concentrations in the 60-minute samples. We conclude that the topical application of either etidocaine or bupivacaine is a safe procedure in the doses and concentrations used during general antaesthesia for laparoscopic tubal banding.

\section{Key words}

ANAESTHETICS, LOCAL: bupivacaine, etidocaine, metabolism; PAIN: postoperative; sURGERY: laparoscopy, tubal ligation.

From Department of Anesthesiology, University of Pittsburgh School of Medicine and Magee-Womens Hospital, Forbes Ave. and Halket St., Pittsburgh, Pennsylvania 15213. Address correspondence to: Dr. R. McKenzie.
Lidocaine, bupivacaine, and etidocaine have been applied to the fallopian tubes to relieve the pain of tubal occlusion performed with the use of local anaesthesia, with intravenous sedation and with general anaesthesia. ${ }^{1-3}$ The doses of local anaesthetics used vary widely. We reported a significant reduction in narcotic requirement in the recovery period when etidocaine was applied to the fallopian tubes before occlusion during laparoscopy. ${ }^{3}$ The frequency of overnight stay in hospital was also significantly reduced. The safety and effectiveness of etidocaine compared with other local anaesthetics used for this purpose have not been studied. We therefore designed a double-blind, randomized clinical trial to compare the clinical effectiveness of bupivacaine and etidocaine. The safety of topical application was evaluated by measuring the blood concentrations of the local anaesthetics along with their metabolites.

\section{Methods}

With the approval of our hospital human investigation committee, informed consent was obtained from 22 healthy outpatients having laparoscopic tubal occlusion under general anaesthesia. They were randomly assigned to one of two groups.

All patients received fentanyl $50 \mu \mathrm{g}$ and droperidol $1.25 \mathrm{mg}$ IV followed by preoxygenation and precurarization. Anaesthesia was then induced with thiamylal 5 $\mathrm{mg} \cdot \mathrm{kg}^{-1}$, followed by succinylcholine, $100 \mathrm{mg}$, to facilitate tracheal intubation. Anaesthesia was maintained with 50 per cent nitrous oxide and oxygen with $0.5-2$ per cent isoflurane. Following induction, a heparinized cannula was placed in a vein in the forearm not used for IV infusion, and a baseline blood sample was obtained. Nitrous oxide was insufflated to create the operative pneumoperitoneum needed for the surgery.

Patients in Group $E$ had one per cent etidocaine, 2 $\mathrm{mg} \cdot \mathrm{kg}^{-1}$, and patients in Group B had 0.75 per cent bupivacaine, $1.5 \mathrm{mg} \cdot \mathrm{kg}^{-1}$, applied to both fallopian tubes from uterus to fimbria. A $20 \mathrm{ml}$ syringe containing the unknown local anaesthetic was attached to a Kiddy cannula and dripped onto the fallopian tube under direct vision via the laparoscope. We previously established the 
ETIDOCAINE and BUPIVACAINE BLOOD LEVELS

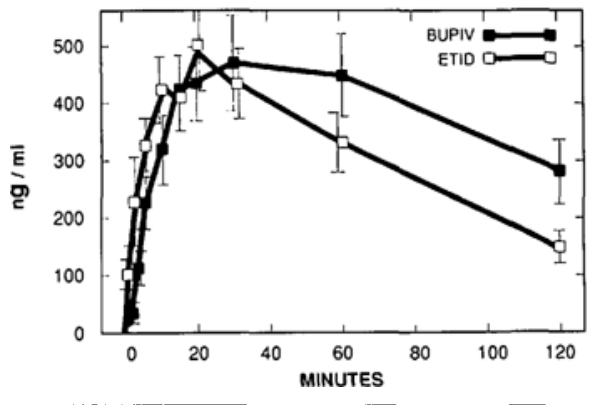

FIGURE 1 Venous whole blood levels $\pm S E M$ of etidocaine $2 \mathrm{mg} \cdot \mathrm{kg}^{-1}$ $\square$ and bupivacaine $1.5 \mathrm{mg} \cdot \mathrm{kg}^{-1} \square$ following intraabdominal, topical application during laparoscopy. $n=11$ in each group.

clinical effectiveness of 1 per cent etidocaine ${ }^{3}$ and selected 0.75 per cent bupivacaine to obtain its maximum effect. Numbered syringes were prepared by one of the authors (AFV) according to the patient's weight. A $50 \mathrm{~kg}$ patient would require $10 \mathrm{ml}$ of either drug in the syringe thereby precluding recognition of the solution and assuring double-blindness of surgical and anaesthetic personnel. The application of the unknown local anaesthetic was completed prior to tubal occlusion with Falope bands. At $1,3,6,10,15,30,60$ and $120 \mathrm{~min}$ after application, $2 \mathrm{ml}$ samples of venous blood were drawn.

Whole blood was analyzed in triplicate by highpressure liquid chromatography (HPLC) for etidocaine and its metabolites, 2-amino-2'-butyroxylidide (ABX), 2-N-propylamino-2'butyroxylidide (PBX), and 2-Nethylamino-2'butyroxylidide (EBX) in Group $\mathrm{E}$ and for bupivacaine and its metabolite 2,6-pipecoloxylidide (PPX) in Group B. The samples were collected using nonheparinized syringes and immediately placed in a borate solution buffered to $\mathrm{pH} 9.5$. The extraction was a two-step technique. The samples were first extracted into $10 \mathrm{ml}$ of 30 per cent methylene chloride and then back extracted into $150 \mu \mathrm{l}$ of $0.1 \mathrm{~N} \mathrm{HCl}$. All samples were frozen and later analyzed by HPLC using a reversedphase technique described by Kennedy et al. ${ }^{4}$ Bupivacaine was used as the internal standard for the etidocaine and metabolite analyses, and etidocaine as the internal standard for the bupivacaine and PPX analyses. Ultraviolet detection was used with a wavelength of $210 \mathrm{~nm}$ for maximum absorbance. Detection limits were etidocaine, $10 \mathrm{ng} \cdot \mathrm{ml}^{-1}$; bupivacaine, $15 \mathrm{ng} \cdot \mathrm{ml}^{-1} ; \mathrm{ABX}, 5 \mathrm{ng} \cdot \mathrm{ml}^{-1}$; PPX, $5 \mathrm{ng} \cdot \mathrm{ml}^{-1}$; EBX, $5 \mathrm{ng} \cdot \mathrm{ml}^{-1}$; and PBX, $5 \mathrm{ng} \cdot \mathrm{ml}^{-1}$. Standard curves were constructed and validated daily; they were found to be linear, $r^{2} \geqq 0.99$, for all compounds of interest.
On arrival at the recovery room and at $0.5,1$ and $2 \mathrm{hr}$ after termination of anaesthesia, the degree and site of pain, occurrence of nausea or vomiting, and medication(s) administered were recorded by an anaesthetist (RMCK or BMM) blinded to the local anaesthetic used. Subjective abdominal pain was assessed by the anaesthetist by asking the same questions of each patient. "Are you comfortable?" With a positive response, the patient was then asked specifically, "Are you having any abdominal pain?" If so, she would classify the pain as mild, moderate or severe. With a negative response to the first question, the specific follow-up question on abdominal pain was asked. Nausea and vomiting were evaluated as $0=$ nil, 1 $=$ nausea, and $2=$ vomiting. $A$ follow-up telephone call was made the next day to record persistent or new complications.

Data were analyzed for statistical significance using the Fisher exact probability test. Level of $P \leq .05$ was considered statistically significant.

\section{Results}

The two groups were similar in age, weight, height, haematocrit and duration of operation. With Group E, the mean peak whole blood concentration ( \pm SEM) was $501.8 \pm 71.3 \mathrm{ng} \cdot \mathrm{ml}^{-1}$; with a range of $222-905 \mathrm{ng} \cdot \mathrm{ml}^{-1}$ (Figure 1). Corresponding values for Group B were 468.8 $\pm 73.8 \mathrm{ng} \cdot \mathrm{ml}^{-1}$ with a range of $191-1005 \mathrm{ng} \cdot \mathrm{ml}^{-1}$. Mean peak concentrations occurred at $17.7 \mathrm{~min}$ (range 6-30 $\mathrm{min}$ ) with etidocaine and at $33.2 \mathrm{~min}$ (range 10-60 min) with bupivacaine (Table I). There were rapid, parallel increases in blood concentrations of both parent drugs during the first $15 \mathrm{~min}$. After $20 \mathrm{~min}$, etidocaine levels began to decrease. Bupivacaine levels reached a plateau from $20-60 \mathrm{~min}$ before slowly declining. Blood concentrations of both drugs decayed at a similar rate (Figure 1). The metabolic degradation products of etidocaine, ABX, PBX, and EBX, were all present in the 1-min sample (Figure 2). The major metabolite of bupivacaine, PPX, did not consistently appear until the 60-min sample (Figure 3).

In the recovery room, pain was significantly less in Group E patients (Table II), $P<0.05$. No subjective abdominal pain was reported in 28 of 42 observations ( 66.6 per cent), mild pain 13 of 42 (31 per cent) and moderate pain one of 42 (2.4 per cent). In Group B, no subjective abdominal pain was reported in 13 of 42 ( 40.5 per cent) and moderate pain 12 of 42 (28.5 per cent). No patient in either group had severe abdominal pain. Statistical significance $P<0.5$ was reached for patients with no pain and moderate pain. Group $E$ patients had less moderate pain and more patients reported no pain compared with group $B(P<0.5)$. Intravenous fentanyl $50 \mu \mathrm{g}$ in divided doses was necessary in one patient in Group $B$. 
TABLE I Venous blood concentrations after topical application of etidocaine and bupivacaine

\begin{tabular}{|c|c|c|c|c|c|c|}
\hline \multirow[b]{2}{*}{ Group } & \multirow[b]{2}{*}{$n$} & \multicolumn{2}{|c|}{$\begin{array}{l}\text { Peak concentration } \\
\left(n g \cdot m^{-1}\right)\end{array}$} & \multicolumn{3}{|c|}{$\begin{array}{l}\text { Time to maximum concentration } \\
\text { (min) }\end{array}$} \\
\hline & & Mean* & Range & Mean* & Median & Range \\
\hline Etidocaine & 11 & $501.8 \pm 71.3$ & $222-905$ & $17.7 \pm 1.8$ & 20 & $10-30$ \\
\hline Bupivacaine & 11 & $468.0 \pm 73.8$ & $191-1005$ & $33.2 \pm 5.7$ & 30 & $6-60$ \\
\hline
\end{tabular}

$* \pm$ SEM.

Values obtained by high pressure liquid chromatography and time to maximum peak concentrations of etidocaine and bupivacaine.

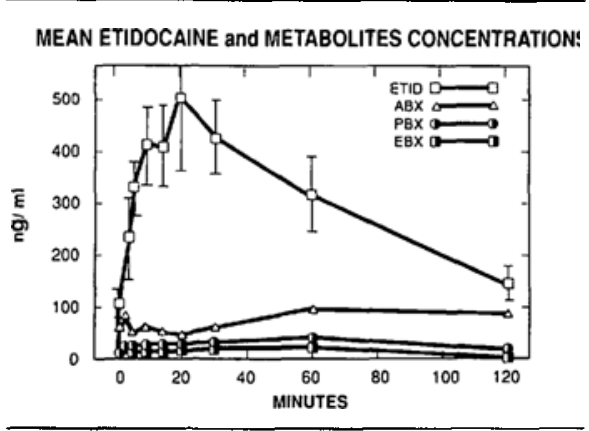

FIGURE 2 Whole blood levels of etidocaine $\square$ and major metabolites $\mathrm{ABX}, \mathrm{PBX}$ and EBX following intrabdominal, topical application during laparoscopy. (Note the rapid appearance and amount of 2-amino$2^{\prime}$-butyroxylidide (ABX) $\triangle$ and the small amount of 2-N-propylamino2 butyroxylidide (PBX) $\bigcirc$ and 2-N-ethylamino-2' butyroxylidide (EBX) 口.) $n=11$.

An equal number of patients in both groups required oral analgesics (acetaminophen - oxycodone - acetaminophen [Percoset], or ibuprofen).

Nausea occurred in three patients in Group $\mathrm{E}$ and in two patients in Group B. Vomiting occurred three times in two patients given bupivacaine. There was no significant difference in the incidence of nausea or vomiting in the two groups. At $24 \mathrm{hr}$ one patient in each group complained of lower abdominal pain.

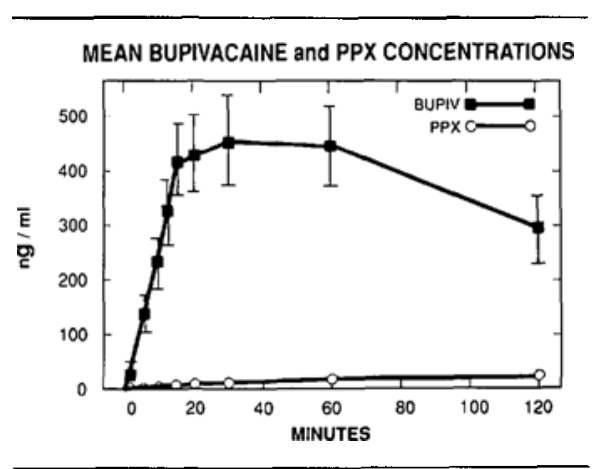

FIGURE 3 Whale blood levels of bupivacaine $\boldsymbol{\square}$ and ils major metabolite 2,6-pipecoloxylidide (PPX) $\bigcirc$ following intraabdominal, topical application during laparoscopy. (Note the slow metabolism of parent drug bupivacaine $\mathbf{D}$ to 2,6-pipecoloxylidide (PPX) 0 .) $n=11$.

\section{Discussion}

The intraoperative, intraperitoneal instillation of local anaesthetic agents to reduce pain has been used for many years. In 1950, Hanson and Hingson reported on seven patients who successfully underwent laparotomy with $500-1200 \mathrm{mg}$ intraperitoneal lidocaine. 'The average duration of action was $45 \mathrm{~min}$. Cruikshank et al. found that nonconvulsive blood levels were attained with 1000 mg lidocaine in nonpregnant women having tubal occlu-

TABLE II Abdominal pain reported after topical application of etidocaine and bupivacaine during tubal acclusion

\begin{tabular}{lllllll}
\hline & \multicolumn{5}{c}{ Degree of pain } & \\
\cline { 3 - 6 } Group & $n$ & Ni* & Mild & Moderate* & Severe & \# Observationst \\
\hline Etidocaine & 11 & 28 & 13 & 1 & 0 & 42 \\
Bupivacaine & 11 & 13 & 17 & 12 & 0 & 42 \\
\hline
\end{tabular}

$* P<0.05$.

fFour observations could not be obtained: in group $E$, one on anival at recovery room and one at $2 \mathrm{hr}$; in group B, two on arrival at recovery room. 
sion under local anaesthesia supplemented with preoperative IV alphaprodine and diazepam. ${ }^{2}$ For postpartum tubal ligation using the same analgesic and sedative dnigs, subconvulsive blood levels of lidocaine were also found when $500 \mathrm{mg}$ lidocaine was used. ${ }^{2}$

Abdominal pain after laparoscopic tubal occlusion is severe in most patients, lasts from $4-6 \mathrm{hr}$, and may delay discharge from day surgery units. ${ }^{3}$ Postoperative pain is more severe following laparoscopic sterilization than when diagnostic laparoscopy alone is performed, and for this reason studies of morbidity from laparoscopy patients having laparoscopic sterilization may be excluded. ${ }^{5}$ Davis and Millar found that the laparoscopic sterilization patients have significantly more pain in the first $4 \mathrm{hr}$ after surgery than diagnostic laparoscopy patients $(P<0.02){ }^{6}$

Etidocaine and bupivacaine were selected in the present study because extended duration of action is needed to provide postoperative comfort. However, both drugs have been implicated in cases of cardiac arrest following epidural and probably inadvertent intravascular administration. ${ }^{7}$ Topical application avoids intravascular injection, but rapid absorption of the drug could still lead to toxic blood levels with convulsion and/or cardiac arrest. Although the clinical effectiveness of etidocaine one per cent and bupivacaine 0.5 per cent has been reported independently, blood analyses to verify the safety of intraabdominal instillation have not. ${ }^{3,8}$

In the doses and concentrations that we compared, the patients in Group $E$ complained of less severe abdominal pain than those in Group B. Although there were only 11 patients in each group, 84 spoken subjective pain assessments were made. Without valid doseresponse curves for each drug, the difference in effectiveness is not easily explained. Etidocaine differs from bupivacaine in physical properties, especially $\mathrm{pKa}$ and lipid solubility. At body $\mathrm{pH}$ etidocaine $(\mathrm{pKa}=7.74)$ is less ionized than bupivacaine ( $\mathrm{pKa}=8.01$ ). Etidocaine has a partition coefficient of 141 and is approximately five times as soluble in fat as bupivacaine. ${ }^{28}$ Both drugs are 90-96 per cent protein bound. If more etidocaine is available to penetrate nervous tissue there may be more active ionized drug to account for superior pain relief.

The weight-normalized dose that produces seizures in rhesus monkeys is higher for etidocaine than for bupivacaine; etidocaine is therefore considered less toxic. ${ }^{9}$ Plasma concentrations at seizure of these two drugs are similar. Having established an effective dose of etidocaine, ${ }^{3}$ we chose a dose of bupivacaine estimated to result in similar blood levels. To maximize the effectiveness of topical bupivacaine, the highest concentration was chosen. The similar peak blood concentrations may be attributable to the higher lipid solubility and more rapid metabolism of etidocaine. A high metabolite concentra- tion would imply greater safety for system toxicity by reducing the concentration of parent drug.

The earliest peak concentration for etidocaine at six minutes and for bupivacaine at ten minutes demonstrated that drugs placed intraabdominally may be absorbed rapidly into the bloodstream. Close patient surveillance is necessary for one hour because the latest peak concentrations occurred at $30 \mathrm{~min}$ for Group $\mathrm{E}$ and $60 \mathrm{~min}$ for Group B. The blood level of a local anaesthetic parent drug is altered by the rapidity of metabolites produced. Etidocaine has three metabolites which appear quickly, indicating rapid metabolism by the liver. The early appearance of $A B X, P B X$ and $E B X$ and the increase in concentration over time account for the decrease in etidocaine level. Similarly, bupivacaine levels remained high throughout the study with a low metabolite level for PPX. It is believed that none of these metabolites adds to the toxicity of the parent drugs. Our doses avoided toxicity as confirmed by serial blood analyses. The mean peak blood concentration was one-quarter of the reported minimal convulsive level of $2 \mu \mathrm{g} \cdot \mathrm{ml}^{-1}$ in monkeys ${ }^{9}$ and oneeighth of the arterial plasma levels that caused convulsions in humans. ${ }^{10}$

Reduction of etidocaine concentrations, and hence its safety, appears to be related to metabolism. There is a possibility that absorption may in part be into the portal circulation rather than systemic, but this study could not determine differential absorption. Wide variations were noted in the venous blood levels. For etidocaine the range was from 222 to $905 \mathrm{ng} \cdot \mathrm{ml}^{-1}$, while bupivacaine values

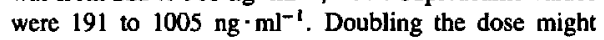
achieve convulsive levels in some patients. These results do not apply to procedures carried out under local anaesthesia, because possible cumulative effects of additional local anaesthetic agent could reach a convulsive level.

In summary, topical application of either etidocaine or bupivacaine was a safe procedure in the dose and concentration used. Furthermore, intravascular injection is impossible with topical application. The venous blood concentrations of etidocaine and bupivacaine were similar, although quantitatively 33 per cent more etidocaine was applied. The doses used were effective, and peak blood concentrations were below toxic levels despite wide individual variation.

\section{References}

1 Hanson IR, Hingson RA. The use of xylocaine in surgery, obstetrics, and therapeutics. Anesth Analg $1950 ; 29: 136-47$.

2 Cruikshank DW, Laube DW, DeBacker LJ. Intraperitoneal lidocaine anesthesia for postpartum tubal ligation. Obstet Gynecol 1973; 42: 127-30. 
3 McKenzie R, Phitayakorn $P$, Uy NTL, Tantisira B, Wadhwa $R K$, Vicinie $A F$. Topical etidecaine during laparoscopic tubal occlusion for postoperative pain relief. Obstet Gynecol 1986;67: 447-9.

4 Kennedy RL, Miller RP, Bell JU et al. Uptake and distribution of bupivacaine in fetal lambs. Anesthesiology $1986 ; 65: 247-53$.

5 Collins KM, Docherty PW, Plantevin OM. Postoperative morbidity following gynaecological outpatient laparoscopy. A reappraisal of the service. Anaesthesia 1984;39: 819-22.

6 Davis A, Millar JM. Postoperative pain: a comparison of laparoscopic sterilisation and diagnostic laparoscopy. Anaesthesia 1988; 43: 796-7.

7 Albright GA. Cardiac arrest following regional anesthesia with etidocaine or bupivacaine. Anesthesiology 1979;51: 285-7.

8 Spielman FJ, Hulka JF, Ostheimer GW, Mueller RA. Pharmacokinetics and pharmacodynamics of local analgesia for laparoscopic tubal ligations. Am J Obstet Gynecol 1983;146: 821-3.

9 Munson ES, Tucker WK, Ausinsch B, Malagodi MH. Etidocaine, bupivacaine, and lidocaine seizure thresholds in monkeys. Anesthesiology 1975;42: 471-8.

10 Moore DC, Balfour $R$, Fitzgibbons $D$. Convulsive arterial plasma levels of bupivacaine and the response to diazepam therapy. Anesthesiology 1979; 50: 454-6.
Résumé

Le but de cette étude est de comparer l'efficacité et la sécurité de l'étidocaine et de la bupivacaine pour l'analgésie postoperatoire apres ligature tubaire par laparoscopie. Cette étude comprend 22 patientes en bonne santé ayant reçu soit un pour cent d'étidocaine, $2 \mathrm{mg} \cdot \mathrm{kg}^{-1}$, ou de la bupivacaine 1,5 $m g \cdot \mathrm{kg}^{-1}$ d'une façon radomisée d̀ double insu. L'anesthésique fut mis sur les tubes de fallope d̀ partir de l' utérus jusqu'aux franges avant la ligature tubaire. Afin d'établir la sécurite, les concentrations sanguines du médicament et de ses métabolites ont été mesurées avant l' application et à $1,3,6,10,15,30,60$ et 120 minutes. Les concentrations maximales moyennes éraient de $501,8 \pm 71,3$ (SEM) pour l'étidocaïne avec un écart de 225 a $905 \mathrm{ng} \cdot \mathrm{ml}^{-1}$. Pour la bupivacaine, la concentration maximale moyenne était de $468 \pm 73,8 \mathrm{SEM}$ avec un écart de 191 a 1005 $n g \cdot \mathrm{ml}^{-1}$. Les valeurs moyennes étaient de $1 / 8$ de la dose toxique provoguant des convulsions chez les humains. L'étidocaine étain métabolisée à un taux supérieur d̀ la bupivacaine avec une apparition rapide de la 2-amino-2'-butyroxylidide (ABX). La métabolite de la bupivacaine 2,6-pipécoloxylidide (PPX) était détectée à des concentrations basses aux échantillons de 60 minutes. On conclut que l' application topique de l' étidocaïne ou de la bupivacaïne est sécuritaire à des doses et des concentrations utilisées en anesthésie générale pour ligature tubaire. 